\title{
Boala Wilson la copil - criterii şi scoruri de diagnostic
}

\author{
Alexandra Coroleucă', Daniela Păcurar ${ }^{1,2}$, Coriolan Emil UImeanu' ${ }^{1,2}$ \\ ${ }^{1}$ Spitalul Clinic de Urgenţă pentru Copii „Grigore Alexandrescu“, Bucureşti, România \\ 2Universitatea de Medicină şi Farmacie „Carol Davila“, Bucureşti, România
}

\begin{abstract}
REZUMAT
Boala Wilson este o afecţiune genetică, transmisă autozomal recesiv, ce determină tulburări ale metabolismului cuprului, ducând la acumularea acestuia în ţesuturile ţintă. Este o afecţiune multisistemică şi are tablou clinic foarte polimorf. Stabilirea diagnosticului pozitiv poate fi dificilă, nefiind disponibil un singur test care să confirme sau să infirme cu certitudine această afecţiune. Au fost stabilite criterii de diagnostic pentru boala Wilson iniţial pentru pacienţii adulţi, ulterior au fost reevaluate pentru copil. Stabilirea diagnosticului precoce permite iniţierea terapiei chelatoare la timp, ceea ce oferă un prognostic bun, încetinind progresia bolii. De aceea, se pune foarte mult accentul pe importanţa screening-ului familial.
\end{abstract}

Cuvinte cheie: copil, boala Wilson, criterii de diagnostic

\section{INTRODUCERE}

Boala Wilson (BW) reprezintă o tulburare severă a metabolismului cuprului, ce este exprimată clinic printr-un spectru larg de manifestări hepatice, neurologice, oculare, renale, psihiatrice, hematologice şi, în cazuri mai rare, endocrinologice, osoase, cutanate etc. BW este determinată de mutaţii la nivelul genei ATP7B ce codifică ATP-aza transportoare de cupru, având ca urmări acumularea cuprului în organele ţintă $(1,2)$. Incidenţa afecţiunii a fost în creştere în ultimii ani, estimată la 1:30.000 (3). Este o afecțiune cronică, invalidantă, ce necesită tratament chelator toată viaţa. Stabilirea diagnosticului precoce şi iniţierea terapiei chelatoare încetinesc evoluţia bolii şi oferă un prognostic bun. Din aceste motive screeningul familial este recomandat ca metodă de diagnostic încă din perioada asimptomatică sau presimptomatică (4) şi, de asemenea, se recomandă screening-ul generaţiei anterioare (5).

Diagnosticul pozitiv de BW este dificil de stabilit deoarece tabloul clinic este foarte variabil, pacienţii pot avea numeroase fenotipuri clinice. Niciunul dintre testele de laborator disponibile nu este specific pentru BW şi nu stabileşte cu certitudine diagnosticul (6). Dacă această afecţiune nu este re- cunoscută şi nu este tratată la timp, evoluţia bolii hepatice poate fi rapidă către ciroză şi insuficienţă hepatică. De asemenea, odată cu întârzierea terapiei, pot apărea leziuni ireversibile ale sistemului nervos central (3).

Pacientul cu suspiciune de BW necesită o evaluare complexă, multidisciplinară: evaluarea funcţiei hepatice, studii imagistice şi histologice hepatice, evaluare neurologică şi neuroimagistică, psihiatrică, oftalmologică, testare genetică. În acelaşi timp, trebuie acordată atenţie deosebită familiei prin efectuarea screening-ului, cu scopul de a identifica pacienţii asimptomatici (7).

Stabilirea diagnosticului se face prin coroborarea datelelor clinice şi paraclinice. Pe baza acestora se calculează scorul de diagnostic. O valoare a scorului $\geq 4$ este înalt sugestivă pentru diagnosticul de BW.

\section{Manifestările clinice în boala Wilson la copil}

Conform studiilor recente, s-a stabilit faptul că BW poate apărea la orice vârstă între 3 ani şi 74 ani (în medie 13,2 ani), dar rareori simptomatică înainte de vârsta de 5 ani (8). BW este o afecţiune multisistemică având un tablou clinic variabil. În prime- 
le decade de viaţă, predomină manifestările hepatice. După vârsta de 20 ani, 75\% dintre cazuri se prezintă cu manifestări neurologice, iar $25 \%$ atât cu manifestări hepatice, cât şi neurologice $(9,10)$.

Afectarea hepatică în BW este consecinţa acumulării toxice a cuprului la nivelul hepatocitului, ce determină injurie ireversibilă şi apoptoză. Majoritatea copiilor se prezintă iniţial cu boală hepatică, în general după vârsta de 5 ani (11). Au fost raportate însă şi cazuri de BW hepatică severă la copii mai mici, cu vârstă de 2-3 ani (12). Severitatea bolii hepatice variază de la descoperirea accidentală a citolizei hepatice până la hepatita acută, hepatomegalie, insuficienţă hepatică şi ciroză (13). Dintre pacienţii care au indicaţie de transplant hepatic de urgenţă din cauza insuficienței hepatice acute, 6-12\% au boala Wilson (14). Într-un studiu pe 156 pacienţi cu BW efectuat în Polonia, s-a evidenţiat faptul că $94,23 \%$ dintre cazurile de pacienţi cu BW s-au prezentat cu manifestări hepatice, dintre care $16,23 \%$ cu insuficienţă hepatică (15). Ciroza hepatică poate fi prezentă în unele cazuri de la diagnostic $(16,17)$.

Noile recomandări ale Societăţii Europene de Gastroenterologie, Hepatologie şi Nutriţie Pediatrică (ESPGHAN) sunt de a suspiciona BW la orice copil cu vârstă mai mare de 1 an, care prezintă orice semn de boală hepatică de la citoliză asimptomatică la ciroză hepatica cu hepatomegalie şi ascită sau insuficienţă hepatică acută (recomandare Grad 1A, nivel de acord $86 \%$ ) (3).

Manifestările neurologice ale bolii sunt consecinţa depunerii cuprului predominant la nivelul ganglionilor bazali (nucleu caudat, putamen, globus pallidus), dar şi la nivel talamic şi, ocazional, la nivelul trunchiului cerebral (18). Deşi simptomele neurologice/psihiatrice de obicei apar în a doua sau a treia decadă a vieţii, pot ocazional să fie prezente înainte de vârsta de 10 ani şi au fost raportate la 4-6\% dintre cazurile de copii şi adolescenţi cu debut hepatic (11).

Cel mai frecvent întâlnite manifestări neurologice şi psihiatrice ale BW sunt enumerate în Tabelul 1.

TABELUL 1. Manifestări neurologice şi psihiatrice frecvent întâlnite în BW

\begin{tabular}{|l|l|}
\hline Manifestări neurologice & Manifestări psihiatrice \\
\hline Tulburări motorii & Depresie \\
(tremor, mişcări involuntare, coree) & Tulburări de personalitate \\
Hipersalivație, dizartrie & Psihoză \\
Distonie rigidă & Comportament nevrotic \\
Pareză pseudobulbară & \\
Dizautonomie & \\
Cefalee migrenoasă & \\
Insomnie & \\
Convulsii & \\
\hline
\end{tabular}

Conform recomandărilor ESPGHAN, BW ar trebui exclusă la orice adolescent cu tulburări cognitive, psihiatrice sau de tulburări motorii inexplicabile (recomandare Grad 1A, nivel de acord 96\%) (3).

Inelul pericornean Kayser-Fleischer (IKF) şi cataracta ,în floarea soarelui“" reprezintă manifestările oftalmologice ale BW. Ambele manifestări sunt reversibile cu terapia medicamentoasă sau după transplantul hepatic. IKF reprezintă marca bolii Wilson şi apare în urma depunerii cuprului la nivelul membranei corneene Descemet. Unii pacienţi pot prezenta doar schiţe de IKF. Prezenţa acestuia este înalt sugestivă pentru diagnostic. Poate lipsi la pacienţii de vârstă mică, la cei cu patologie hepatică. În 95\% dintre cazuri este prezent la pacienţii cu simptomatologie neurologică (19).

Anemia hemolitică Coombs-negativă poate fi singura manifestare iniţială a bolii Wilson. Hemoliza marcată este frecvent asociată cu afecţiunea hepatică cronică. Lezarea celulelor hepatice eliberează cantităţi mari de cupru care agravează hemoliza (1). Anemia hemolitică severă asociată cu insuficienţă hepatică poate fi un indiciu pentru BW. Hemoliza izolată este rar întâlnită în absenţa afectării hepatice semnificative. Diagnosticul este îngreunat în cazul în care anemia hemolitică este simptomul inaugural (20).

Alte manifestări sau forme de prezentare ale BW sunt mai rar întâlnite. Acestea sunt enumerate în Tabelul 2.

TABELUL 2. Alte manifestări mai rare ale BW (21-25)

\begin{tabular}{|l|l|}
\hline Organ țintă & Manifestare clinică \\
\hline Rinichi & $\begin{array}{l}\text { Disfuncție tubulară renală (sindrom } \\
\text { Fanconi, acidoză tubulară renală, } \\
\text { aminoacidurie) } \\
\text { Nefrolitiază } \\
\text { Nefrocalcinoză }\end{array}$ \\
\hline Cord & $\begin{array}{l}\text { Cardiomiopatie } \\
\text { Aritmii }\end{array}$ \\
\hline Sistem endocrin & $\begin{array}{l}\text { Hipogonadism hipogonadotrofic secundar } \\
\text { afecțiunii cronice hepatice } \\
\text { Hipoparatiroidism } \\
\text { Tulburări ale ciclului menstrual } \\
\text { Infertilitate }\end{array}$ \\
\hline $\begin{array}{l}\text { Sistem } \\
\text { osteoarticular }\end{array}$ & $\begin{array}{l}\text { Osteopenie, osteoporoză } \\
\text { Artrită }\end{array}$ \\
\hline Cutanate & Lipoame, lunuae cerulae \\
\hline Gastrointestinale & Pancreatită \\
\hline
\end{tabular}

\section{Teste paraclinice folosite pentru diagnosticul bolii Wilson la copil}

Evaluarea funcţiei hepatice. În formele uşoare de afectare hepatică, se poate constata un sindrom de citoliză hepatică moderată, cu valorile transami- 
nazelor în intervalul 100-500 UI. În formele severe de boală, asociate cu insuficienţă hepatică, se întâlnesc în mod tipic valori foarte crescute ale bilirubinei serice $(>17,5 \mathrm{mg} / \mathrm{dl})$ şi valori scăzute ale fosfatazei alcaline, cu raport fosfatază alcalină (UI)/ bilirubină $\mathrm{mg} / \mathrm{dl}<1$. Aceste caracteristici nu sunt totuşi patognomonice pentru BW (3).

Ceruloplasmina serică este transportorul major al cuprului în sânge. De asemenea, este un reactant de fază acută. Concentraţia de ceruloplasmină serică este scăzută la nou-născuţi, apoi crește treptat cu vârsta, atingând un maxim la jumătatea copilăriei, înainte de a scădea uşor în timpul pubertăţii (26). Din acest motiv, se recomandă determinarea ceruloplasminei după vârsta de 1 an. Concentraţia ceruloplasminei este $<20 \mathrm{mg} / \mathrm{dl}$ la majoritatea pacienţilor cu BW (27). Nivelurile serice scăzute se întâlnesc, de asemenea, în aproximativ 20\% dintre cazurile de purtători heterozigoţi, pacienţi cu insuficienţă hepatică, malabsorbţie, tulburări de glicozilare, boală Menkes, malnutriţie protein-calorică, sindrom nefrotic, enteropatie cu pierdere de proteine, deficit de cupru dobândit şi aceruloplasminemie ereditară (6). Studiile recente au arătat că cel mai bun prag al valorii ceruloplasminei care conferă precizie diagnosticului, a fost $<14 \mathrm{mg} / \mathrm{dl}$ (cu sensibilitate de $93 \%$ şi specificitate de $100 \%$ ), întrun studiu în care au fost incluşi 57 de pacienţi adulţi şi copii cu BW ce prezentau disfuncţie hepatică şi/ sau deficite neurologice (28). Valoarea cut-off a ceruloplasminei $<20 \mathrm{mg} / \mathrm{dl}$ a avut o sensibilitate $95 \%$ şi specificitate $84,5 \%$, într-un studiu în care au fost incluşi 40 de copii cu citoliză asimptomatică (29).

Cupremia sau cuprul seric total include valoarea cuprului liber, nelegat de ceruloplasmină şi cuprul legat de ceruloplasmină. În BW, valoarea cupremiei poate fi scăzută, normală sau crescută. Cuprul „liber“, nelegat de ceruloplasmină, poate fi calculat folosind următoarea formulă:

\section{[cuprul total seric $(\mu \mathrm{g} / \mathrm{dl})-(3,15 \mathrm{x}$ ceruloplasmina serică $(\mathbf{m g} / \mathbf{d l})]$}

Valorile cuprului liber sunt reduse la pacienţii care primesc tratament, de obicei sunt situate între 5 şi $15 \mu \mathrm{g} / \mathrm{dl}$. Acest marker este foarte util în monitorizarea tratamentului pacienţilor cu BW $(30,31)$.

Cupruria/24 ore cuantifică excreţia urinară de cupru în 24 de ore. La copiii cu forme asimptomatice sau la copiii cu afecţiuni hepatice uşoare, valorile cupruriei sunt adesea normale. Pragul de diagnostic a fost stabilit la valoarea de $40 \mathrm{mg} / 24$ ore ( $0,65 \mathrm{mmol} / 24$ ore $)$ cu o sensibilitate de $78,9 \%$ şi o specificitate de $87,9 \%$ (29). Testul de provocare cu penicilamină se realizează prin administrarea a 500 mg D-penicilamină la începutul colectării urinei pe 24 de ore şi încă $500 \mathrm{mg}$ administrate cu 12 ore mai târziu. Nu este un test fiabil pentru excluderea diagnosticului în cazurile asimptomatice (sensibilitate $12 \%$ şi specificitate $46 \%$ ) pentru valoarea cut-off de $1.575 \mathrm{mg} / 24$ ore $(25 \mathrm{mmol} / 24$ ore $)$. Reducerea valorii cut-off la $200 \mathrm{mg} / 24$ ore (3,2 mmol/24 ore) a crescut sensibilitatea la $88 \%$, dar a dus la o scădere considerabilă a specificităţii la $24,1 \%(3,32)$.

Măsurarea cuprului interschimbabil relativ (relative exchangeable copper) este un test nou propus şi folosit în anumite centre pentru diagnosticul BW. Acest test se referă la determinarea fracţiunii de cupru seric labil, care este legat de albumină şi de alte peptide. Un studiu recent a evidenţiat faptul ca această test are specificitate şi sensibilitate de $100 \%$ pentru diagnosticul BW la adulţi, cu o valoare cut-off de $15 \%$ (15). Potrivit recomandărilor ESPGHAN, acest test necesită studii suplimentare la copiii cu afectare hepatică, pentru evaluarea acurateţii sale diagnostice (3).

Testarea genetică a crescut remarcabil rata de diagnostic, în special în cazurile în care datele clinice şi paraclinice sunt dificil de interpretat. Sunt mai mult de 500 mutaţii ale genei ATP7B implicate în BW. Au fost identificaţ̧i şi indivizi heterozigoţi compuşi $(32,33)$. Există o distribuţie regională a mutaţiilor genetice. Anumite mutaţii au fost descrise cu frecvenţă mai mare în diferite regiuni geografice astfel: în Europa de Est, cea mai frecventă mutaţie este H1069Q, în Spania - Met645Arg, în Sardinia s-a identificat mai frecvent mutaţia c-441 427del15, în Japonia - 229insC, Arg778Leu, Costa Rica - Asp1279Ser iar în China, Coreea şi Taiwan este mai frecventă mutaţia Arg778Leu. Cunoaşterea frecvenţei acestor mutaţii facilitează diagnosticul molecular, prin efectuarea testelor genetice rapide, specific $(30,34)$. În România, întâmpinăm dificultăţi în această etapa de lucru, din cauza disponibilităţii reduse a testelor genetice şi a costurilor ridicate asociate. Pentru testarea genetică avem disponibile unele teste care studiază 4 mutaţii din cele 500 de mutaţii (H1069Q, R778L, A874V şi N1270S). Secvenţierea genelor nu este disponibilă în ţara noastră. Se poate realiza în alte state europene dar costurile sunt foarte ridicate.

Biopsia hepatică pentru diagnosticul de BW este recomandată numai în cazurile în care diagnosticul este neclar. Prin biopsie se poate cuantifica încărcarea hepatică de cupru. Studiul histologic solitar nu poate stabili diagnosticul în absenţa celorlalte criterii. Particularităţile histologice sunt nespecifice în BW şi includ: aspecte de steatoză hepatică (atât microveziculară, cât şi macroveziculară), 
incluziuni de glicogen în nucleii hepatocitelor periportale şi necroză hepatocitară focală, corpi hialini Mallory, care sunt constituiţi din incluziuni citoplasmatice eozinofile formate din proteine citoscheletice, şi inflamaţie asemănătoare cu cea din hepatita autoimună (35). Depunerile de cupru pot fi evidenţiate prin coloraţiile: rodamină, orceină sau coloraţie cu acid rubenic, dar au o valoare de diagnostic limitată. Colorarea negativă nu poate exclude creşterea cantităţii de cupru hepatic, în timp ce colorarea pozitivă este observată în mai multe afecţiuni asociate cu tulburări ale secreţiei biliare (3).

Cuantificarea cuprului intrahepatic se recomandă a se efectua în cazurile în care diagnosticul este echivoc conform noilor recomandări ESPGHAN (3). Conform publicaţiilor recente, valoarea cuprului hepatic mai mare de $250 \mathrm{ug} / \mathrm{g}$ de ţesut uscat (unde valorile normale sunt situate între 15 şi 55 ug/g), acompaniată de valoarea scăzută a ceruloplasminei serice, stabileşte diagnosticul de BW. Trebuie avut în vedere faptul că se întâlnesc concentraţii crescute de cupru hepatic şi în afecţiuni colestatice (ciroză biliară primitivă, colangeită sclerozantă, atrezie biliară, colestază intrahepatică) şi, de asemenea, în toxicozele cuprice nonwilsoniene (ciroza copiilor indieni, ciroză infantilă endemică, toxicoza cuprică idiopatică) (30). Cuantificarea cuprului hepatic nu se poate realiza în ţara noastră.

Screening-ul familial. Consilierea genetică este recomandată atât de ghidurile europene, cât şi de cele americane $(1,36)$. Este obligatoriul screeningul fraţilor pacienţilor cu BW, deoarece şansa de a fi homozigot şi a face boala este de $25 \%$ (3). Evaluarea ar trebui să includă examenul fizic complet, determinarea ceruloplasminei serice, testele funcţiei hepatice şi teste moleculare pentru mutaţiile ATP7B. Screening-ul nou-născutui nu este justificat şi poate fi amânat până la vârsta de 1-2 ani (5).

Scorul de diagnostic. Pentru a facilita diagnosticul, în anul 2001, un consens internaţional de experţi în domeniu a propus un sistem de punctare, alcătuind un scor de diagnostic, folosind aspecte clinice, parametrii biochimici (ceruloplasmina serică, cupruria/24 ore) şi diagnosticarea moleculară. Acest scor, cunoscut şi sub numele de Scorul Ferneci (Tabelul 3), a fost adoptat ulterior pentru baza de date Eurowilson (37).

Valoarea diagnostică a scorului a fost studiată şi în populaţia pediatrică. Pentru o valoare cut-off de 4 s-au identificat sensibilitate $98 \%$, specificitate $97 \%$ pentru diagnosticul pozitiv. În cazurile cu simptomatologie uşoară, însă scorul a arătat valori predictive pozitive şi negative mai mici. Limitele scorului sunt legate de faptul că evaluarea prin suma punctelor depinde de corectitudinea determinărilor efectuate. De asemenea, unele criterii nu pot fi aplicate la copii cu vârste mici (2). Pentru cazurile pediatrice s-au efectuat câteva modificări ale scorului de la Leipzig (29). Aceste modificări sunt prezentate în tabelul 3 .

TABELUL 3. Scorul diagnostic în BW (Scorul Ferenci) (6)

\begin{tabular}{|c|c|c|c|}
\hline Semne şi simptome clinice & Scor & Biochimie & Scor \\
\hline $\begin{array}{l}\text { Inel Kayser-Fleischer } \\
\text { Prezent } \\
\text { Absent }\end{array}$ & $\begin{array}{c}+1 \\
0\end{array}$ & $\begin{array}{l}\text { Conținutul de cupru hepatic (în absența } \\
\text { colestazei) } \\
>5 \text { LSN }(50-250 \mu \mathrm{g} / \mathrm{g} \text { țesut uscat) } \\
<5 \text { LSN }(50-250 \mu \mathrm{g} / \mathrm{g} \text { țesut uscat) } \\
\text { Normal }(<0,8 \mu \mathrm{mol} / \mathrm{g})\end{array}$ & $\begin{array}{l}+2 \\
+1 \\
-1\end{array}$ \\
\hline $\begin{array}{l}\text { Simptome neuropsihiatrice sugestive sau modificări } \\
\text { tipice evidențiate la RMN cerebral } \\
\text { Severe } \\
\text { Moderate } \\
\text { Absente }\end{array}$ & $\begin{array}{c}+2 \\
+1 \\
0\end{array}$ & $\begin{array}{l}\text { Granule Rodanin pozitive } \\
\text { (în cazul în care nu se poate realiza } \\
\text { cuantificarea cuprului hepatic) } \\
\text { Absente } \\
\text { Prezente }\end{array}$ & $\begin{array}{c}0 \\
+1 \\
\end{array}$ \\
\hline $\begin{array}{l}\text { Anemie hemolitică Coombs negativă + cupremie } \\
\text { crescută } \\
\text { Prezentă } \\
\text { Absentă }\end{array}$ & $\begin{array}{c}+1 \\
0\end{array}$ & $\begin{array}{l}\text { Ceruloplasmina serică } \\
\text { Normal (> } 20 \mathrm{mg} / \mathrm{dl}) \\
10-20 \mathrm{mg} / \mathrm{dl} \\
<10 \mathrm{mg} / \mathrm{dl}\end{array}$ & $\begin{array}{c}0 \\
+1 \\
+2\end{array}$ \\
\hline $\begin{array}{l}\text { Genotipare (analiza genetică ATP7B) } \\
\text { Mutație detectată pe ambii cromozomi } \\
\text { Mutație detectată pe un singur cromozom } \\
\text { Fără mutație detectată }\end{array}$ & $\begin{array}{c}+4 \\
+1 \\
0\end{array}$ & $\begin{array}{l}\text { Cupruria (în absența hepatitei acute) } \\
\text { Normal } \\
1-2 \text { X LSN } \\
>2 \text { LSN } \\
\text { Normal, dar > } 5 \text { LSN după testul de } \\
\text { provocare cu D penicilamină }\end{array}$ & $\begin{array}{c}0 \\
+1 \\
+2 \\
+2\end{array}$ \\
\hline \multicolumn{4}{|c|}{$\begin{array}{l}\text { Scor total > 4- probabilitate foarte mare pentru BW } \\
\text { Scor total 2-3 - diagnostic probabil, dar necesită testare suplimentară } \\
\text { Scor total 0-1 - diagnostic improbabil } \\
\text { LSN* - limita superioară a normalului }\end{array}$} \\
\hline
\end{tabular}




\section{CONCLUZII}

BW poate îmbrăca numeroase aspecte fenotipice. Este important sa fie recunoscute principalele semne şi simptome ale bolii pentru a ghida algoritmul investigaţional necesar stabilirii diagnosticului. Uneori, stabilirea diagnosticului pozitiv poate fi extrem de dificilă şi laborioasă. Criteriile de diagnostic Ferenci vin în ajutorul clinicianului, facilitând diagnosticul. Criteriile şi algoritmul investiga-

\section{BIBLIOGRAFIE}

1. Ferenci P, Czlonkowska A, Stremmel W, Houwen R, Rosenberg W, Schilsky M et al. EASL Clinical Practice Guidelines: Wilson's disease. J Hepatol. 2012 Mar;56(3):671-85.

2. Robers $E$, Socha P. Wilson disease in children. Członkowska $A$, Schilsky ML, editors. Handb Clin Neurol. Vol. 142. 2017;142:141-56.

3. Socha P, Janczyk W, Dhawan A et al. Wilson's disease in children: A position paper by Hepatology Commitee of the European Society for Paediatric Gastroenterology, Hepatology and Nutrition. JPGN. 2018;66:334-44.

4. Li H, Liu L, Li Y et al. Familial screening of children with Wilson disease: Necessity of screening in previous generation and screening methods. Med (Baltimore). 2018;97(27):e11405.

5. Brunet A-S, Marotte S, Guillaud O et al. Familial screening in Wilson's disease: Think at the previous generation! J Hepatol. 2012; 57(6):1394-5.

6. Ferenci P. Diagnosis of Wilson disease. In: Handbook of Clinical Neurology. 2017. p. 171-80.

7. Moraru A. Epidemiological features and socioeconomic burden in childhood Wilson Disease. Rev Română Econ. 2015;1(49):198-209.

8. Lin L, Wang D, Ding N, Zheng C. Hepatic Manifestations in Wilson's Disease: Report of 110 Cases. Hepatogastroenterology. 2015; 62(139):657-60.

9. Riordan SM, Wiliams R. Wilson's disease gene and phenotipic diversity. J Hepatol. 2001;34:165-71.

10. Roberts E, Schilsky ML. AASLD Practice Guidelines: Diagnosis and Treatment of Wilson Disease. Wiley Intersci. 2008;2089-111.

11. Rukunuzzaman M. Wilson's disease in Bangladeshi children: Analysis of 100 cases. Pediatr Gastroenterol Hepatol Nutr. 2015;18:121-127.

12. Wilson DC, Phillips MJ, Cox DW, Roberts EA. Severe hepatic Wilson's disease in preschool-aged children. J Pediatr. 2000; 137(5):719-22.

13. Merle U, Schaefer M, Ferenci P et al. Clinical presentation, diagnosisand long-term outcome of Wilson's disease: a cohort study. Gut. 2007;56:115.

14. Eisenbach C, Sieg O, Stremmel W, Encke J, Merle U. Diagnostic criteria for acute liver failure due to Wilson disease. World $\mathrm{J}$ Gastroentero. 2017; 13:1711-1714.

15. Naroniakoeska M, Dadalski M, Kaminska D et al. Clinical presentation of Wilson disease among polish children. Dev Period Med. 2016; 20(3):216-21.

16. Shah D. Wilson's disease: Hepatic manifestations. Disease-a-month. 2014; 60:465-74.

17. Przybyłkowski A, Gromadzka G, Chabik $G$ et al. Liver cirrhosis in patients newly diagnosed with neurological phenotype of Wilson's disease. Funct Neurol. 2014;29(1):23-29.

18. Członkowska A, Litwin T, Chabik G. Wilson disease: Neurologic features. Handb Clin Neurol. 2017;142:101-19.

19. Hedera P. Update on clinical management of Wilson disease. Appl Clin Genet. 2017;10:9-19.

20. Balkema S, Hamaker ME, Visser HPJ et al. Haemolytic anaemia as first sign of Wilson's disease. Neth J Med. 2008;66:344-7. ţional trebuie adaptate disponibilităţiilor şi statutului socio-economic al ţării. Determinarea ceruloplasminei serice şi cupruria/24 ore sunt disponibile şi ne pot orienta către diagnostic. În cazurile incerte, se recomandă testarea genetică sau biopsia hepatică. Odată diagnosticat un caz de boală Wilson, trebuie realizat screening-ul familial. Vor fi evaluaţi fraţii pacientului, dar şi părinţii, pentru a putea identifica noi cazuri de boală din perioada asimptomatică sau presimptomatică.

Conflict of interest: none declared Financial support: none declared

21. Wang $\mathrm{H}$, Zhou Z, Hu J et al. Renal impairment in different pnehnotypes of Wilson disease. Neurol Sci. 2015;36(11):2111-5.

22. Soni D, Shukla G, Singh $S$ et al. Cardiovascular and sudomotor autonomic disfunction in wilson disease - limitted correlation with clinical severity. Aut Neurosci. 2009;151(2):154-8.

23. Weiss KH, Van de Moortele M, Gotthardt DN et al. Bone demineralisation in a large cohort of Wilson disease patients. J Inherit Metab Dis. 2015;38(5):949-56.

24. Krysiak R, Handzlik-Orlik G, Okopien B. Endocrine Symptoms as the Initial Manifestation of Wilson's Disease. Yale J Biol Med. 2012;249-54.

25. Karrunya KJ, Bavanandam S, Dheivamani N, Vijayabhaskar CR, Manoharan K. Spectrum of cutaneous manifestations in Wilson's disease in children in a tertiary care center in South India: A prospective study. Int J Contemp Pediatr. 2017;4:2060-2064.

26. Kelly J, Raizman JE, Bevilacqua $V$ et al. Complex reference value distributions and partitioned reference intervals across the pediatric age range for 14 specialized biochemical markers in the CALIPER cohort of healthy community children and adolescents. Clin Chim Acta 2015;450:196-202.

27. Merle U, Eisenbach C, Weiss KH et al. Serum ceruloplasmin oxidase activity is a sensitive and highly specific diagnostic marker for Wilson's disease. J Hepatol. 2009;51:925-930.

28. Mak CM, Lam CW, Tam S. Diagnostic accuracy of serum ceruloplasmin in Wilson disease: determination of sensitivity and specificity by ROC curve analysis among ATP7B-genotyped subjects. Clin Chem. 2008;54:1356-1362.

29. Nicastro E, Ranucci G, Vajro P et al. Re-evaluation of the diagnostic criteria for Wilson disease in children with mild liver disease. Hepatology. 2010;52:p1948.

30. Schilsky ML. Wilson Disease and Related Disorders. In: Handbook of Liver Disease. 4th ed. 2018. p. 263-8.

31. Liu J, Luan J, Zhou X, Cui Y, Han J. Epidemiology, diagnosis, and treatment of Wilson's disease. Vol. 6, Intractable and Rare Diseases Research. 2017.

32. Seo JK. Diagnosis of Wilson disease in young children: Molecular genetic testing and a paradigm shift from the laboratory diagnosis. PGHN. 2012;15(4):197-209.

33. Stoicanescu D, Belengeanu V, Stoian M et al. Clinical value of melecular testing in patients with Wilson disease. Rev Rom Med Lab. 2011;19:373-9.

34. Ferenci P. Regional distribution of mutations of the ATP7B gene in patients with Wilson disease: Impact on genetic testing. Hum Genet. 2006; 120(2):151-9.

35. Pronicki M. Wilson disease - liver pathology. Handb Clin Neurol. 2017;142:71-5.

36. Robers E, Schilsky ML. Diagnosis and treatment of Wilson's disease an update. Hepatology. 2008;47:2089-111.

37. Ferenci P, Caca K, Loudianos $G$ et al. Diagnosis and phenotypic classification of Wilson disease. Liver Int. 2003;23:139-42. 